\title{
Pengaruh Dimensi Keadilan, Sosialisasi Pajak, Sanksi Pajak, Penghasilan Wajib Pajak dan Pemeriksaan Pajak Terhadap Kepatuhan WPOP UMKM
}

\author{
Putu Nadiani Putri Utama ${ }^{1}$ \\ Putu Ery Setiawan ${ }^{2}$ \\ ${ }^{1,2}$ Fakultas Ekonomi dan Bisnis Universitas Udayana (Unud), Bali, Indonesia \\ e-mail: nadianinana28@gmail.com
}

\begin{abstract}
ABSTRAK
Penelitian ini bertujuan untuk mengetahui pengaruh dari dimensi keadilan, sosialisasi pajak, sanksi pajak, penghasilan wajib pajak, dan pemeriksaan pajak terhadap kepatuhan wajib pajak orang pribadi Usaha Mikro, Kecil, dan Menengah (UMKM) yang terdaftar pada Kantor Pelayanan Pajak (KPP) Pratama Gianyar tahun 2017. Teori yang digunakan dalam penelitian ini adalah Teori Atribusi dan Theory of Planned Behaviour. Sebanyak 100 Wajib Pajak Orang Pribadi UMKM yang terdaftar di KPP Pratama Gianyar dipilih menjadi responden dengan menggunakan rumus slovin. Metode penelitian yang digunakan adalah accidental sampling dengan menggunakan media kuisioner dan teknis analisis data penelitian ini menggunakan analisis uji asumsi klasik dan regresi linier berganda. Hasil penelitian ini menunjukkan bahwa dimensi keadilan, sosialisasi pajak, sanksi pajak, penghasilan wajib pajak, dan pemeriksaan pajak berpengaruh positif dan signifikan terhadap kepatuhan wajib pajak orang pribadi UMKM.

Kata kunci: Kepatuhan wajib pajak UMKM, dimensi keadilan, sosialisasi, sanksi, penghasilan, pemeriksaan pajak.
\end{abstract}

\begin{abstract}
This study aims to determine the effect of the dimensions of justice, socialization of taxes, tax sanctions, income taxpayers, and tax audits of individual taxpayer compliance Micro, Small and Medium Enterprises (MSMEs) registered at the Pratama Tax Service Office (KPP) Gianyar in 2017. The theories used in this study are Attribution Theory and Theory of Planned Behavior. A total of 100 MSME Personal Taxpayers registered at KPP Pratama Gianyar were selected as respondents using the Slovin formula. The research method used was accidental sampling using media questionnaires and technical analysis of the data of this study using classical assumption test analysis and multiple linear regression. The results of this study indicate that the dimensions of justice, tax socialization, tax sanctions, income of taxpayers, and tax audits have a positive and significant effect on taxpayer compliance with individual SMEs.
\end{abstract}

Keywords: UMKM taxpayer compliance, dimensions of justice, socialization, sanctions, income, tax audit.

\section{PENDAHULUAN}

Undang - Undang No. 23 Tahun 2007 Tentang Ketentuan Umum dan Tata Cara

Perpajakan Pasal 1 Ayat 1 menegaskan bahwa pajak adalah kontribusi wajib

kepada Negara yang terutang oleh orang pribadi atau badan yang bersifat 
memaksa berdasarkan Undang-Undang, dengan tidak mendapatkan imbalan secara langsung dan digunakan untuk keperluan Negara bagi sebesar-besarnya kemakmuran rakyat. Indonesia yang merupakan salah satu Negara berkembang, dimana pembangunan disegala bidang terus-menerus dilakukan oleh pemerintah tentu memerlukan biaya yang besar. Semakin besarnya biaya yang digunakan untuk pembangunan maka semakin besar juga penerimaan atau pemasukan yang diperlukan oleh negara, yang dalam hal ini sangat bergantung pada penerimaan pajak, penerimaan bukan pajak serta hibah (Apsari, 2017)

Penerimaan Negara dari sektor pajak menjadi salah satu sumber utama bagi pemerintah Indonesia dalam membiayai pelaksanaan pembangunan nasional yang bertujuan untuk meningkatkan kesejahteraan dan kemakmuran masyarakat Indonesia. Penerimaan pajak yang semakin besar dijadikan sebagai suatu wujud kemampuan untuk membiayai kegiatan pembangunan dari seluruh komponen bangsa. Target Anggaran Pendapatan dan Belanja Negara sektor pajak mengalami peningkatan setiap tahunnya, namun hal ini tidak diimbangi dengan realisasi yang belum mencapai target.

Tabel 1.

Target dan Realisasi Penerimaan Negara Sektor Pajak 2013-2017 (triliun

\begin{tabular}{lccccc}
\multicolumn{7}{c}{ upiah) } \\
\hline \multicolumn{1}{c}{ Tahun } & 2013 & 2014 & 2015 & 2016 & 2017 \\
\hline Target & 995,21 & 1072,38 & 1294,26 & 1355,2 & 1283,6 \\
Realisasi & 921,39 & 985,13 & 1060,8 & 1069,9 & 1151,1 \\
\% Realiasi & 92,58 & 91,86 & 81,97 & 78,95 & 89,68 \\
\hline
\end{tabular}

Sumber: Data diolah, 2018

Tabel 1 menunjukkan besarnya target penerimaan pajak dan realisasinya dari tahun 2013 sampai 2017 masih belum mencapai target 100 persen. Tax Ratio Indonesia sebagai indikator yang dapat menentukan kinerja otoritas pajak (Eben 
Ezer, 2017) memiliki nilai paling kecil diantara Negara ASEAN lainnya seperti pada Tabel 2.

Tabel 2.

Tax Ratio Negara ASEAN Tahun 2011-2015 (dalam \%)

\begin{tabular}{llllll}
\hline \multicolumn{1}{c}{ Negara } & 2011 & 2012 & 2013 & 2014 & 2015 \\
\hline Indonesia & 11,12 & 11,38 & 11,29 & 10,84 & 10,75 \\
Singapura & 13,28 & 13,85 & 13,49 & 13,85 & 13,63 \\
Malaysia & 14,79 & 15,61 & 15,31 & 14,84 & 14,30 \\
Filipina & 12,38 & 12,89 & 13,31 & 13,61 & 13,63 \\
Thailand & 16,36 & 15,44 & 17,29 & 15,94 & 16,28 \\
\hline
\end{tabular}

Sumber: Data diolah, 2018

Hal ini menunjukkan masih rendahnya peran aktif dari masyarakat Indonesia untuk ikut serta memberikan kontribusinya untuk pendapatan Negara melalui kepatuhan dalam membayarkan kewajiban pajaknya. Kepatuhan pajak merupakan suatu sikap atau perilaku wajib pajak yang melaksanakan semua kewajiban perpajakannya dan menikmati hak perpajakannya sesuai dengan ketentuan peraturan perundang-undangan yang berlaku (Marjan, 2014). Kepatuhan wajib pajak dalam membayar pajak dapat memengaruhi pendapatan Negara, karena apabila tingkat kepatuahan rendah maka akan memengaruhi tingkat pendapatan Negara.

Telah banyak upaya yang dilakukan oleh Direktorat Jendral Pajak untuk mendorong peningkatan penerimaan Negara melalui pajak. Pemerintah saat ini berupaya mereformasi sistem perpajakan menuju sistem perpajakan yang lebih berkeadilan, serta perluasan data yang lebih valid komprehensif dan terintegrasi dalam rangka penerimaan pajak jangka pendek maupun jangka panjang (Marjan, 2014). Setelah reformasi perpajakan pada tahun 1983 Official Assessment System sudah tidak berlaku lagi digantikan oleh Self Assessment System yaitu 
memberikan kepercayaan penuh kepada Wajib Pajak untuk menghitung, menyetor dan melaporkan seluruh pajak yang menjadi kewajibannya (Tarjo dan Kusumawati, 2006).

Pemerintah juga telah menerbitkan PP No. 46 Tahun 2013 yang mengatur tentang perlakuan pajak penghasilan untuk Usaha Mikro, Kecil, dan Menengah (UMKM). Peraturan ini dikeluarkan pemerintah dengan substansinya adalah pungutan pajak sebesar 1 persen dari penghasilan usaha yang diterima atau diperoleh wajib pajak dengan peredaran bruto tidak melebihi Rp4,8 miliar dalam 1 tahun, peraturan ini berlaku mulai 1 Juli 2013. Dengan adanya peraturan ini diharapkan dapat memudahkan UMKM dalam menghitung, menyetor dan melaporkan Pajak Penghasilan terutangnya.

UMKM merupakan unit usaha yang paling dominan di Indonesia, sehingga kontribusi UMKM terhadap PDB setiap tahunnya terus meningkat. Berdasarkan data dari Kementrian Koperasi dan UMKM menunjukkan bahwa UMKM menyumbang pada PDB sebesar 62,57 persen dari total PDB yang terbagi menjadi 38,90 persen usaha mikro, sebesar 9,73 persen usaha kecil dan 13,95 persen usaha menengah. Dengan semakin meningkatnya jumlah pertumbuhan UMKM, diharapkan semakin meningkat pula kepatuhan UMKM dalam membayar pajak sehingga dapat memberikan kontribusi pada peningkatan penerimaan pajak.

Besarnya potensi penerimaan pajak dari UMKM diharapkan tidak hanya terjadi pada tingkat nasional saja melainkan hingga tingkat kabupaten, salah 
satunya di Kabupaten Gianyar dengan tingkat kepatuhan pajak yang dapat dilihat pada tabel berikut.

Tabel 3.

Tingkat Kepatuhan Wajib Pajak Orang Pribadi UMKM di KantorPelayanan Pajak Pratama Gianyar Periode 2014 - 2017

\begin{tabular}{ccccc}
\hline Tahun & $\begin{array}{c}\text { Jumlah UMKM } \\
\text { yang Terdaftar }\end{array}$ & $\begin{array}{c}\text { WPOP UMKM } \\
\text { yang Melaporkan } \\
\text { SPT }\end{array}$ & $\begin{array}{c}\text { WPOP UMKM yang } \\
\text { Tidak Melaporkan }\end{array}$ & $\begin{array}{c}\text { Tingkat } \\
\text { Kepatuhan } \\
(\%)\end{array}$ \\
\hline 2014 & 5.999 & 3.965 & 2.034 & 66,1 \\
2015 & 7.323 & 5.186 & 2.137 & 70,8 \\
2016 & 8.540 & 5.287 & 3.253 & 61,9 \\
2017 & 10.393 & 5.241 & 5.151 & 50,4 \\
\hline
\end{tabular}

Sumber: Data diolah, 2018

Pada Tabel 3 dapat dilihat tingkat kepatuhan wajib pajak UMKM yang terdapat di KPP Pratama Gianyar cenderung menurun. Presentase kepatuhan Wajib pajak orang pribadi UMKM pada tahun 2014 sebesar 66,1 persen mengalami peningkatan menjadi sekitar 70,8 persen pada tahun 2015. Namun pada tahun 2016-2017 tingkat kepatuhan mengalami penurunan yang cukup signifikan. Pada tahun 2016 tingkat kepatuhan turun menjadi 61,9 persen dan menurun kembali pada tahun 2017 menjadi 50,4 persen. Hal ini menunjukkan bahwa tingkat kepatuhan pajak WPOP UMKM di KPP Pratama Gianyar masih jauh di bawah target kepatuhan pajak nasional yang telah ditetapkan Direktorat Jendral Pajak berdasarkan aras Surat Edaran Nomor SE-07/PJ/2016 yaitu sebesar 70 persen.

Hal tersebut yang menjadikan alasan peneliti untuk meneliti lebih lanjut terkait dengan menurunnya tingkat kepatuhan pajak di tiga tahun terakhir serta belum tercapainya target tingkat kepatuhan yang telah ditetapkan oleh Direktorat Jendral Pajak. Maka hal ini membutuhkan suatu kajian sehingga mengetahui gambaran mengenai faktor-faktor apa saja yang dapat memengaruhi Wajib Pajak 
dalam kepatuhan mereka membayar pajak. Terdapat beberapa faktor yang perlu diperhatikan dalam menilai kepatuhan dari wajib pajak. Seperti dimensi keadilan, sosialisasi pajak, sanksi pajak, penghasilan wajib pajak, dan pemeriksaan pajak.

Dimensi keadilan merupakan salah satu faktor non-ekonomi kunci dari tingkat kepatuhan wajib pajak (Richardson, 2006). Wajib pajak akan patuh dalam melaksanakan kewajiban membayar pajak jika wajib pajak merasakan keadilan umum berupa adanya manfaat yang didapatkan oleh wajib pajak baik secara tidak langsung dalam bentuk peningkatan penyediaan fasilitas umum, serta keadilan dalam bentuk beban pajak yang dikenakan kepada wajib pajak sesuai dengan kemampuan wajib pajak itu sendiri (ability to pay). Hal ini didukung oleh penelitian yang dilakukan oleh Azmi dan Perumal (2008), variabel dimensi keadilan menunjukkan hubungan positif yaitu memengaruhi kepatuhan wajib pajak.

Untuk lebih meningkatkan pemahaman wajib pajak mengenai peraturan pajak yang berlaku, perlu adanya sosialisasi yang teratur oleh pemerintah dalam hal ini Direktorat Jendral Pajak. Sosialisasi dapat dilakukan secara langsung kepada wajib pajak disuatu daerah atau secara tidak langsung berupa spanduk atau flayer. Hal ini sesuai dengan penelitian yang dilakukan oleh Megantara (2017) bahwa sosialisasi berpengaruh terhadap kepatuhan wajib pajak.

Sanksi pajak juga merupakan salah satu variabel yang dapat memengaruhi kepatuhan wajib pajak untuk melaksanakan kewajibannya. Pemerintah dalam hal ini Direktorat Jendral Pajak harus tegas dalam menerapkan sanksi kepada wajib pajak yang melanggar, sehingga akan menimbulkan efek jera kepada pelanggar. 
Penelitian yang dilakukan oleh Aditya Pranata (2015), Sari (2018) dan Eben Ezer (2017) menghasilkan bahwa sanksi pajak berpengaruh positif terhadap kepatuhan pajak. Namun ada pula beberapa penelitian yang menyebutkan tidak signifikannya pengaruh sanksi pajak terhadap kepatuhan pajak seperti pada penelitian Chusnul Chotimah (2007) dan Asfa (2017).

Beberapa penelitian juga menemukan penghasilan berpengaruh terhadap tingkat kepatuhan wajib pajak. Apabila wajib pajak berada dalam kondisi mengalami kerugian atau tidak mendapatkan keuntungan yang cukup dalam usahanya, wajib pajak akan cenderung untuk tidak taat dalam memenuhi kewajiban dalam membayar pajak dikarenakan masih terdapat kebutuhankebutuhan lainnya yang lebih penting dari membayar pajak itu sendiri. Megantara (2017) dalam penelitiannya menemukan hasil bahwa tingkat penghasilan berpengaruh secara signifikan terhadap kepatuhan wajib pajak dalam melaksanakan kewajiban membayar pajak.

Tinggi rendahnya tingkat kepatuhan wajib pajak juga dipengaruhi oleh pemeriksaan pajak. Pemeriksaan pajak merupakan serangkaian kegiatan untuk mencari, mengumpulkan, mengelola data dan keterangan lainnya untuk menguji kepatuhan dari wajib pajak sesuai dengan ketentuan perundang - undangan yang berlaku yang dilakukan oleh Dirjen Pajak (Menteri Keuangan Indonesia, 2000). Penerapan sistem Self Assesment System yang memberikan kepercayaan terhadap wajib pajak dalam melaporkan beban pajaknya sendiri dapat meningkatkan ketidakpatuhan oleh wajib pajak berupa kecurangan dalam pelaporan pajak. 
Pemeriksaan pajak sangat diperlukan sebagai bentuk pengawasan terhadap wajib pajak agar wajib pajak tetap berada dalam peraturan pajak yang berlaku. Pada penelitian yang dilakukan Palil (2010) ditemukan hasil bahwa pemeriksaan pajak dapat mendorong wajib pajak untuk lebih patuh dalam mengisi dan melaporkan SPT Tahunan Pajak Penghasilan. Sehingga jika wajib pajak mengetahui mereka akan diperiksa maka ini akan memengaruhi tingkat kepatuhan wajib pajak dalam melaporkan pajak (Richardson, 2006 ).

Penelitian ini merupakan replikasi dari Kadek Megantara (2017) dengan menambahkan variabel dimensi keadilan, serta probabilitas pemeriksaan dan lokasi penelitian yang berbeda. Penambahan variabel dimensi keadilan dimaksudkan mengenai persepsi wajib pajak terhadap tariff dan maaft pajak bagi wajib pajak dan variabel pemeriksaan pajak berkaitan dengan Self Assesment System yang diterapkan di Indonesia memerlukan pengawasan untuk menghindari pelanggaran aturan pajak. Berdasarkan uraian latar belakang di atas maka peneliti tertarik untuk melakukan penelitian dengan judul pengaruh dimensi keadilan, sosialisasi pajak, sanksi pajak, penghasilan wajib pajak dan pemeriksaan pajak terhadap tingkat kepatuhan pelaporan wajib pajak orang pribadi usaha mikro, kecil dan menengah yang terdaftar pada Kantor Pelayanan Pajak Pratama Gianyar. Dimensi keadilan berhubungan dengan persepsi wajib pajak mengenai apakah sistem pajak yang telah berlangsung pelaksanaannya tidak menyimpang dari peraturan yang berlaku. Berdasarkan theory of planned behavior terkait dengan behavioral beliefs, masyarakat akan menilai apakah jumlah pajak yang dibebankan telah sesuai dan adil sesuai dengan tingkat penghasilan yang 
didapatkan serta manfaat yang nantinya akan mereka dapatkan ketika telah melaksanakan kewajiban perpajakan. Apabila dimensi keadilan dalam perpajakan menunjukkan respon yang baik dari wajib pajak, maka perilaku kepatuhan wajib pajak akan meningkat. Penjelasan ini diperkuat dengan penelitian dari Giligan dan Richardson (2005) yang menyebutkan bahwa dimensi keadilan berpengaruh terhadap tingkat kepatuhan wajib pajak. Renata (2016) dan Suryadi (2016) menemukan hasil yang sama, dimana varabel dimensi keadilan dapat memengaruhi perilaku kepatuhan dimasyarakat. Namun terdapat perbedaan pada penelitian yang dilakukan oleh Pris (2010) yang menemukan tidak adanya pengaruh antara dimensi keadilan terhadap tingkat kepatuhan pajak. Penelitian ini akan menguji kembali pengaruh dimensi keadilan, sehingga adapun rumusan hipotesis adalah sebagai berikut.

$\mathrm{H}_{1}$ : Dimensi keadilan berpengaruh positif terhadap Kepatuhan Wajib Pajak Orang Pribadi UMKM.

Sosialisasi dilaksanakan untuk memberikan pengertian kepada wajib pajak mengenai aturan maupun perundang - undangan mengenai pajak. Sesuai dengan Theory of Reason Behavior individu akan melakukan sesuatu apabila terdapat nilai normatif yang akan didapatkan yang berasal dari luar, dalam hal ini wajib pajak mendapatkan motivasi dan dorongan untuk memenuhi kewajiban dalam membayarkan pajak mereka. Terlebih dengan adanya aturan baru yaitu UU No. 46 Tahun 2013 yang diharapkan dapat meningkatkan tingkat kepatuhan wajib pajak dari aturan sebelumnya.

Berdasarkan penelitian yang dilakukan oleh Megantara (2017) sosialisasi pajak berpengaruh positf terhadap tingkat kepatuhan wajib pajak. Selain itu 
penelitian oleh Dharma dan Suardana (2014) serta Fernando (2018) juga menemukan hasil yang sama yaitu sosialisasi pajak berpengaruh positif dengan tingkat kepatuhan wajib pajak. Namun dalam penelitian Yogatama (2014), Setyoningrum (2014), dan Sormi, et al. (2017) menemukan hasil bahwa tidak adanya hubungan yang signifikan antara sosialisasi pajak dengan tingkat kepatuhan dari wajib pajak.

Dikarenakan adanya perbedaan hasil penelitian, maka peneliti tertarik untuk menemukan pengaruh sosialisasi pajak terhadap tingkat kepatuhan Wajib pajak orang pribadi UMKM, sehingga adapun hipotesis yang didapat yaitu,

$\mathrm{H}_{2}$ : Sosialisasi pajak berpengaruh positif terhadap Kepatuhan Wajib Pajak Orang Pribadi UMKM.

Berdasarkan teori Atribusi, sanksi pajak merupakan salah satu faktor eksternal yang dapat memengaruhi tingkat kepatuhan wajib pajak. Wajib pajak akan melaksanakan kewajiban membayar pajak ketika mereka memandang bahwa sanksi pajak akan merugikan mereka, dikarenakan semakin banyaknya pajak terhutang yang dimiliki wajib pajak, maka akan semakin berat bagi wajib pajak dalam melunasinya ditambah dengan denda yang akan didapatkan dikarena keterlambatan dalam pembayaran pajak. Hal ini juga sejalan dengan Theory of Planned Behavior yaitu sanksi pajak menjadi control beliefs bagi wajib pajak, dimana wajib pajak akan diberikan sanksi jika tidak melaksanakan kewajiban membayar pajak sesuai dengan aturan yang berlaku. Pada penelitian Fuadi dan Yeni (2013) mendapatkan hasil bahwa sanksi pajak berpengaruh positif terhadap kepatuhan pajak UMKM. Selain itu Sanders, et al. (2008), Aditya (2015), Sari (2018), dan Eben Ezer (2017) juga mendapatkan hasil bahwa wajib pajak 
berpengaruh positif terhadap tingkat kepatuhan wajib pajak. Berkaitan dengan UU No. 46 Tahun 2018 dimungkinkan akan adanya penghindaran pajak yang dilakukan oleh wajib pajak orang pribadi UMKM, sehingga sanksi haruslah bersifat tegas demi menegakkan hukum guna mencapai tujuan untuk meningkatkan kepatuhan wajib pajak. Maka dari itu berdasarkan uraian di atas, dapat dirumuskan hipotesis sebagai berikut,

$\mathrm{H}_{3}$ : Sanksi pajak berpengaruh positif terhadap Kepatuhan Wajib Pajak Orang Pribadi UMKM.

Penghasilan merupakan nilai kekayaan bersih yang mewakili kenaikan potensi mengkonsumsi (Eben Ezer, 2017). Berbagai penelitian menyatakan bahwa profitabilitas perusahaan merupakan salah satu faktor yang dapat memengaruhi kepatuhan wajib pajak karena profitabilitas akan memengaruhi perusahaan untuk melaporkan perpajakannya (Mustikasari, 2007). Sesuai dengan teori Atribusi, kepatuhan wajib pajak dipengaruhi oleh faktor internal, dimana faktor internal dapat berupa penghasilan yang dimiliki oleh wajib pajak. Wajib Pajak yang memiliki tingkat keuntungan yang rendah akan memiliki kemungkinan untuk tidak mematuhi kewajiban perpajakannya guna untuk mempertahankan arus kas perusahannya.

Penelitian yang dilakukan oleh Setiawan (2015), Megantara (2017), dan Eben Ezer (2017) menunjukkan bahwa penghasilan wajib pajak berpengaruh terhadap tingkat kepatuhan wajib pajak. Sehingga, berdasarkan urian diatas dapat dirumuskan hipotesis sebagai berikut.

$\mathrm{H}_{4}$ : Penghasilan wajib pajak berpengaruh positif terhadap Kepatuhan Wajib Pajak Orang Pribadi UMKM. 
Pemeriksaan merupakan suatu kegiatan menghimpun dan mengolah data, bukti dan keterangan pendukung yang dilaksanakan secara objektif dan profesional berdasarkan standar yang telah ditetapkan. Pemeriksaan dilakukan dengan tujuan untuk memeriksa dan menemukan penyimpangan dalam pemenuhan kewajiban perpajakannya. Berdasarkan theory of planned behavior terkait dengan control beliefs, makin sering wajib pajak diperiksa, akan semakin patuh wajib pajak tersebut dikarenakan wajib pajak akan merasa bahwa mereka diberikan pengawasan untuk melaksanakan kewajiban mereka sesuai dengan aturan yang berlaku. Hal ini diperkuat dengan pendapat Gupta (2009) bahwa semakin tinggi tingkat kemungkinan pemeriksaan maka akan semakin menuruh tingkat penggelapan pajak. Selain itu berdasarkan teori Atribusi, pemeriksaan pajak termasuk kedalam penyebab ekternal dari kepatuhan wajib pajak. Wajib pajak akan menumbuhkan persepsi bahwa dengan meningkatknya frekuensi pemeriksaan pajak, maka kemungkinan akan mendapatkan bukti mengenai pelaporan pajak yang tidak sesuai peraturan semakin tinggi. Hal ini akan membuat wajib pajak merasa takut, sehingga berusaha meningkatkan kepatuhan dalam membayar pajak sesuai aturan yang berlaku.

Penelitian yang dilakukan oleh Mandagi (2014) ditemukan hasil bahwa pemeriksaan pajak berengaruh positif terhadap tingkat kepatuhan wajib pajak. Hasil ini juga ditemukan pada penelitian yang dilakukan oleh Allingham \& Sandmo (1972), dan Forest \& Sheffrin (2015), Palupi (2017) dan Eben Ezer (2017). Berdasarkan urian tersebut, maka didapatkan rumusan hipotesis.

$\mathrm{H}_{5}$ : Pemeriksaan pajak berpengaruh positif terhadap Kepatuhan Wajib Pajak Orang Pribadi UMKM. 


\section{METODE PENELITIAN}

Lokasi Penelitian ini dilakukan di KPP Pratama Gianyar. Alasan peneliti memilih KPP Pratama Gianyar adalah dikarenakan tingkat pertumbuhan UMKM di Gianyar yang semakin meningkat tidak berbanding dengan tingkat kepatuhan wajib pajak UMKM yang semakin menurun. Oleh karena itu, peneliti ingin melakukan penelitian yang lebih lanjut mengenai apakah variabel dimensi keadilan, sosialisasi perpajakan, sanksi pajak, penghasilan wajib pajak dan pemeriksaan pajak berpengaruh terhadap kepatuhan wajib pajak orang pribadi UMKM.

Populasi pada penelitian ini adalah Wajib Pajak Orang Pribadi UMKM yang terdaftar pada Kantor Pelayanan Pajak Gianyar pada periode 2017 yang memiliki peredaran bruto kurang atau sama dengan $\mathrm{Rp} 4,8$ miliar pertahun. Adapun populasi dalam penelitian ini sejumlah 10.392 Wajib Pajak Orang Pribadi UMKM. Metode penentuan sampel yang digunakan dalam penelitian ini adalah metode accidental sampling. Metode accidental sampling merupakan metode pengambilan sampel secara aksidental dengan mengambil responden yang kebetulan ada atau tersedia di suatu tempat sesuai dengan konteks penelitian. Adapun yang dipilih menjadi responden dalam penelitian ini adalah respondenyang merupakan wajib pajak orang pribadi UMKM yang terdaftar di KPP Pratama Gianyar. Untuk mengetahui jumlah sampel Wajib pajak orang pribadi UMKM dalam penelitian ini digunakan rumus Slovin yakni. 


$$
n=\frac{N}{\left(1+N \cdot e^{2}\right)}
$$

Keterangan :

$\mathrm{n} \quad=$ Jumlah sampel

$\mathrm{N}=$ Jumlah Populasi

$\mathrm{e}=$ Tingkat kesalahan yang ditoleransi (peneliti menggunakan sebesar 10 persen atau 0,1 )

$$
\begin{aligned}
& n=\frac{10.392}{\left(1+10.392 \cdot\left(0,1^{2}\right)\right.} \\
& n=99,04 \\
& n=100 \text { (dibulatkan) }
\end{aligned}
$$

Analisis yang digunakan dalam penelitian ini adalah analisis regresi berganda yaitu model regresi untuk menganalisis lebih dari satu variabel independen. Persamaan regresi yang dirumuskan berdasarkan hipotesis yang dikembangkan adalah sebagai berikut

$$
Y=\alpha+\beta_{1} X_{1}+\beta_{2} X_{2}+\beta_{3} X_{3}+\beta_{4} X_{4}+\beta_{5} X_{5}+\varepsilon
$$

Keterangan :

$\mathrm{Y} \quad=$ Perilaku kepatuhan pajak UMKM

$\alpha \quad=$ Konstanta

$\beta=$ Koefisien regresi variabel $\mathrm{X}_{1-} \mathrm{X}_{5}$

$\mathrm{X}_{1} \quad=$ Dimensi Keadilan

$\mathrm{X}_{2} \quad=$ Sosialisasi Pajak

$\mathrm{X}_{3}=$ Sanksi Pajak

$\mathrm{X}_{4} \quad=$ Penghasilan Wajib Pajak

$\mathrm{X}_{5}=$ Pemeriksaan WajibPajak

$\varepsilon \quad=$ Error

\section{HASIL DAN PEMBAHASAN}

Statistik deskriptif dalam penelitian ini digunakan untuk memberikan informasi mengenai karakteristik variabel - variabel penelitain, antara lain nilai minimum, maksimum, rata-rata, simpangan baku (standar deviasi) dengan $\mathrm{N}$ adalah 
banyaknya responden penelitian. Hasil statistik deskriptif dapat dilihat pada Tabel 4 sebagai berikut.

Tabel 4.

Hasil Uji Statistik Deskriptif

\begin{tabular}{lccccc}
\hline \multicolumn{1}{c}{ Variabel } & N & Minimum & Maximum & Mean & $\begin{array}{c}\text { Std. } \\
\text { Deviasi }\end{array}$ \\
\hline Kepatuhan WPOP & 100 & 16.00 & 28.00 & 3.28 & 2.453 \\
UMKM (Y) & 100 & 20.00 & 34.00 & 2.82 & 3.217 \\
Dimensi Keadilan $\left(\mathrm{X}_{1}\right)$ & 100 & 8.00 & 16.00 & 3.24 & 1.774 \\
Sosialisasi Pajak $\left(\mathrm{X}_{2}\right)$ & 100 & 11.00 & 19.00 & 3.12 & 1.656 \\
Sanksi Pajak $\left(\mathrm{X}_{3}\right)$ & 100 & 8.00 & 16.00 & 3.16 & 2.324 \\
Penghasilan Wajib Pajak & 100 & 23.00 & 39.00 & 3.24 & 4.130 \\
(X) & & & & &
\end{tabular}

Variabel kepatuhan wajib pajak orang pribadi UMKM memiliki nilai minimum sebesar 16.00 dan nilai maksimum sebesar 28,00. Nilai rata - rata untuk variabel kepatuhan wajib pajak orang pribadi UMKM adalah sebesar 22,98 dengan penyimpangan sebesar 2,453.

Variabel dimensi keadilan memiliki nilai minimum sebesar 20,00 dan nilai maksimum sebesar 34,00. Nilai rata - rata untuk variabel kepatuhan wajib pajak orang pribadi UMKM adalah sebesar 28,21 dengan penyimpangan sebesar 3,217.

Variabel sosialisasi pajak memiliki nilai minimum sebesar 8,00 dan nilai maksimum sebesar 16,00. Nilai rata - rata untuk variabel kepatuhan wajib pajak orang pribadi UMKM adalah sebesar 12,94 dengan penyimpangan sebesar 1,774.

Variabel sanski perpajakan memiliki nilai minimum sebesar 11,00 dan nilai maksimum sebesar 19,00. Nilai rata - rata untuk variabel kepatuhan wajib pajak orang pribadi UMKM adalah sebesar 15,62 dengan penyimpangan sebesar 1,656.

Variabel Penghasilan Wajib Pajak memiliki nilai minimum sebesar 8,00 dan nilai maksimum sebesar 16,00 . Nilai rata - rata untuk variabel kepatuhan wajib 
Putu Ndiani Putri Utama dan Putu Ery Setiawan. Pengaruh ...

pajak orang pribadi UMKM adalah sebesar 12,94 dengan penyimpangan sebesar 2,324 .

Variabel pemeriksaan pajak memiliki nilai minimum sebesar 23,00 dan nilai maksimum sebesar 39,00. Nilai rata - rata untuk variabel kepatuhan wajib pajak orang pribadi UMKM adalah sebesar 32,44 dengan penyimpangan sebesar 4,130.

Perhitungan koefisien regresi linier berganda dilakukan dengan analisis regresi melalui software SPSS 21.0 for Windows, diperoleh hasil yang ditunjukan pada Tabel 5.

Tabel 5.

Hasil Analisis Uji Regresi Linier Berganda

\begin{tabular}{lcccc}
\hline \multicolumn{1}{c}{ Variabel } & $\begin{array}{c}\text { Unstandardized } \\
\text { Beta }\end{array}$ & Std. Error & $\begin{array}{c}\text { Nilai } \\
\text { Sig. }\end{array}$ & $\begin{array}{c}\text { Hasil Uji } \\
\text { Hipotesis }\end{array}$ \\
\hline Constanta & 4,391 & 1,924 & 0,025 & \\
Dimensi Keadilan (X1) & 0,148 & 0,074 & 0,048 & $\mathrm{H}_{1}=$ Diterima \\
Sosialisasi Pajak (X2) & 0,266 & 0,118 & 0,026 & $\mathrm{H}_{2}=$ Diterima \\
Sanksi Pajak (X3) & 0,264 & 0,109 & 0,017 & $\mathrm{H}_{3}=$ Diterima \\
Penghasilan Wajib Pajak (X4) & 0,224 & 0,108 & 0,041 & $\mathrm{H}_{4}=$ Diterima \\
Pemeriksaan Pajak (X5) & 0,124 & 0,059 & 0,040 & $\mathrm{H}_{5}=$ Diterima \\
\hline Sumber: Data diolah, 2019 & & & &
\end{tabular}

Berdasarkan hasil analisis regresi linier berganda seperti yang disajikan pada Tabel 5, maka dapat dibuat persamaan regresi sebagai berikut:

$$
Y=4,391+0,148 X_{1}+0,266 X_{2}+0,264 X_{3}+0,224 X_{4}+0,124 X_{5}
$$


Nilai konstanta $(\alpha)$ menunjukkan besarnya nilai variabel dependen apabila variabel independen adalah 0 (nol). Nilai konstanta sebesar 4,391 memiliki arti jika variabel dimensi keadilan, sosialisasi pajak, sanksi pajak, penghasilan wajib pajak, dan pemeriksaan pajak bernilai nol (0) atau tidak terdapat variabel bebas, maka tingkat kepatuhan wajib pajak orang pribadi UMKM cenderung meningkat sebesar 4,391 dengan nilai signifikansinya $<0,05$. Hal ini diakibatkan oleh adanya variabel lain yang berpengaruh seperti adanya kesadaran maupun kemauan dalam diri wajib pajak dalam melaksanakan kewajiban perpajakan.

Nilai koefisien dimensi keadilan $\left(\mathrm{X}_{1}\right)$ 0,148 menunjukkan arti bahwa dimensi keadilan $\left(\mathrm{X}_{1}\right)$ memiliki hubungan positif pada kepatuhan wajib pajak orang pribadi UMKM. Artinya, jika variabel dimensi keadilan meningkat, maka kepatuhan wajib pajak orang pribadi UMKM akan cenderung meningkat dengan asumsi variabel bebas lainnya konstan.

Nilai koefisien sosialisasi pajak $\left(\mathrm{X}_{2}\right)$ 0,266 menunjukkan arti bahwa sosialisasi pajak $\left(\mathrm{X}_{2}\right)$ memiliki hubungan positif pada kepatuhan wajib pajak orang pribadi UMKM. Artinya, jika variabel sosialisasi pajak meningkat, maka kepatuhan wajib pajak orang pribadi UMKM akan cenderung meningkat dengan asumsi variabel bebas lainnya konstan.

Nilai koefisien sanksi pajak $\left(\mathrm{X}_{3}\right)$ 0,264 menunjukkan arti bahwa sanksi pajak $\left(\mathrm{X}_{3}\right)$ memiliki hubungan positif pada kepatuhan wajib pajak orang pribadi UMKM. Artinya, jika variabel sosialisasi pajak meningkat, maka kepatuhan wajib pajak orang pribadi UMKM akan cenderung meningkat dengan asumsi variabel bebas lainnya konstan. 
Nilai koefisien penghasilan wajib pajak $\left(\mathrm{X}_{4}\right)$ 0,224 menunjukkan arti bahwa penghasilan wajib pajak $\left(\mathrm{X}_{4}\right)$ memiliki hubungan positif pada kepatuhan wajib pajak orang pribadi UMKM. Artinya, jika variabel penghasilan wajib pajak meningkat, maka kepatuhan wajib pajak orang pribadi UMKM akan cenderung meningkat dengan asumsi variabel bebas lainnya konstan.

Nilai koefisien pemeriksaan pajak $\left(\mathrm{X}_{5}\right)$ 0,124 menunjukkan arti bahwa pemeriksaan pajak $\left(\mathrm{X}_{5}\right)$ memiliki hubungan positif pada kepatuhan wajib pajak orang pribadi UMKM. Artinya, jika variabel pemeriksaan pajak meningkat, maka kepatuhan wajib pajak orang pribadi UMKM akan cenderung meningkat dengan asumsi variabel bebas lainnya konstan.

Koefisien determinasi $\left(\mathrm{R}^{2}\right)$ digunakan untuk mengetahui dan mengukur kemampuan model dalam menerangkan variasi variabel independen. Besarnya pengaruh variabel bebas terhadap variabel terikat yang ditunjukkan oleh nilai determinasi total (R Square) sebesar 0,589 mempunyai arti bahwa sebesar 58,9 persen variasi kepatuhan wajib pajak dipengaruhi oleh variasi dimensi keadilan, sosialisasi pajak, sanksi pajak, penghasilan wajib pajak, dan pemeriksaan pajak, sedangkan sisanya sebesar 41,1 persen djelaskan oleh faktor lain yang tidak dimasukkan ke dalam model.

Tabel 6.

Hasil Uji Koefesien Determinasi (adjusted $\mathbf{R}^{2}$ )

\begin{tabular}{ccccc}
\hline Model & $\mathrm{R}$ & $\mathrm{R}$ Square & Adjusted R Square & Std. Error of the Estimate \\
\hline 1 & $.0767^{\mathrm{a}}$ & .589 & .567 & 1.61508 \\
\hline Sumber: Data diolah, 2019 & & &
\end{tabular}

Uji kelayakan model regresi bertujuan untuk mengetahui apakah semua variabel bebas yang diidentifikasi (dimensi keadilan, sosialisasi pajak, sanksi 
pajak, penghasilan wajib pajak, pemeriksaan pajak dan kualitas informasi) tepat digunakan memprediksi kepatuhan wajib pajak. Uji ini sering juga disebut dengan uji F. Hasil Uji $\mathrm{F}$ yang menyatakan signifikan $\mathrm{F}$ atau $\mathrm{P}$ value $<0,05$ maka hubungan antar variabel - variabel bebas adalah signifikan memengaruhi kepatuhan Wajib pajak orang pribadi UMKM di KPP Pratama Gianyar dan model regresi yang digunakan dianggap layal uji. Hasil Uji F disajikan pada Tabel 7 berikut.

Tabel 7.

Hasil Uji Kelayakan Model (Uji F)

\begin{tabular}{llrrrrc}
\hline & Model & Sum of Squares & df & Mean Square & F & Sig. \\
\hline 1 & Regression & 350.764 & 5 & 70.153 & 26.894 & $.000^{\text {a }}$ \\
& Residual & 245.196 & 94 & 2.608 & & \\
& Total & 595.960 & 99 & & & \\
\hline
\end{tabular}

Sumber: Data diolah, 2019

Berdasarkan Tabel 7 diperoleh nilai $F_{\text {hitung }}$ sebesar 26,894 dengan signifkansi sebesar $0,000<0,05$, maka dapat disimpulkan bahwa pada kelompok yang diuji memiliki perbedaan yang nyata (signifikan). Hasil ini mempunyai arti bahwa ada pengaruh signifikan antara dimensi keadilan, sosialisasi pajak, sanksi pajak, penghasilan wajib pajak, dan pemeriksaan pajak secara simultan terhadap kepatuhan wajib pajak.

Uji Hipotesis (Uji t) dilakukan untuk menunjukka pengaruh seluruh variabel independen secara parsial pada variabel dependen. Adapun pengaruh dimensi keadilan, sosialisasi pajak, sanksi pajak, penghasilan wajib pajak dan pemeriksaan pajak terhadap kepatuhan wajib pajak orang pribadi UMKM dapat dilihat dengan membandingkan nilai probabilitas dengan level of significance $(\alpha)$ sebesar 0,05 atau 5 persen. 
Kriteria pengujian untuk menjelaskan interpretasi pengaruh antar masingmasing variabel yakni apabila nilai signifikansi < level of significance 5 persen, maka dimensi keadilan, sosialisasi pajak, sanksi pajak, penghasilan wajib pajak dan pemeriksaan pajak secara parsial berpengaruh terhadap kepatuhan wajib pajak orang pribadi UMKM $\left(\mathrm{H}_{0}\right.$ ditolak dan $\mathrm{H}_{1}$ diterima). Sebaliknya, jika nilai signifikansi > level of significance 5 persen maka dimensi keadilan, sosialisasi pajak, sanksi pajak, penghasilan wajib pajak dan pemeriksaan pajak secara parsial tidak berpengaruh terhadap kepatuhan wajib pajak orang pribadi UMKM $\left(\mathrm{H}_{0}\right.$ diterima dan $\mathrm{H}_{1}$ ditolak). Hasil Uji t disajikan pada Tabel 8 berikut.

Tabel 8.

Hasil Uji Hipotesis (Uji t)

\begin{tabular}{lccl}
\hline \multicolumn{1}{c}{ Variabel } & Sig. uji t & Syarat & Keterangan \\
\hline (Constant) & .025 & $<5 \%$ & \\
Dimensi Keadilan (X1) & .048 & $<5 \%$ & $\mathrm{H}_{1}=$ Diterima \\
Sosialisasi Pajak (X2) & .026 & $<5 \%$ & $\mathrm{H}_{2}=$ Diterima \\
Sanksi Pajak (X3) & .017 & $<5 \%$ & $\mathrm{H}_{3}=$ Diterima \\
Penghasilan Wajib Pajak (X4) & .041 & $<5 \%$ & $\mathrm{H}_{4}=$ Diterima \\
Pemeriksaan Pajak (X5) & .040 & $<5 \%$ & $\mathrm{H}_{5}=$ Diterima \\
\hline
\end{tabular}

Sumber: Data diolah, 2019

Berdasarkan hasil analisis pengaruh dimensi keadilan terhadap kepatuhan wajib pajak pada Tabel 8 , diperoleh nilai signifikasi sebesar 0,048 dengan nilai $\mathrm{t}_{\text {hitung }}$ sebesar 2,006. Nilai Signifikansi 0,048 lebih kecil dari tingkat kesalahan yang dapat diterima yaitu 5 persen atau $0,048<0,05$ mengindikasikan bahwa $\mathrm{H}_{0}$ ditolak dan $\mathrm{H}_{1}$ diterima. Hasil ini mempunyai arti bahwa dimensi keadilan berpengaruh positif dan signifikan terhadap kepatuhan wajib pajak.

Berdasarkan hasil analisis pengaruh sosialisasi pajak terhadap kepatuhan wajib pajak pada Tabel 8, diperoleh nilai signifikasi sebesar 0,026 dengan nilai thitung sebesar 2,263. Nilai Signifikansi 0,026 lebih kecil dari tingkat kesalahan 
yang dapat diterima yaitu 5 persen atau $0,026<0,05$ mengindikasikan bahwa $\mathrm{H}_{0}$ ditolak dan $\mathrm{H}_{2}$ diterima. Hasil ini mempunyai arti bahwa sosialisasi pajak berpengaruh positif dan signifikan terhadap kepatuhan wajib pajak.

Berdasarkan hasil analisis pengaruh sanksi pajak terhadap kepatuhan wajib pajak pada Tabel 8, diperoleh nilai signifikasi sebesar 0,017 dengan nilai $t_{\text {hitung }}$ sebesar 2,433. Nilai Signifikansi 0,017 lebih kecil dari tingkat kesalahan yang dapat diterima yaitu 5 persen atau $0,017<0,05$ mengindikasikan bahwa $\mathrm{H}_{0}$ ditolak dan $\mathrm{H}_{3}$ diterima. Hasil ini mempunyai arti bahwa sosialisasi pajak berpengaruh positif dan signifikan terhadap kepatuhan wajib pajak.

Berdasarkan hasil analisis pengaruh penghasilan wajib pajak terhadap kepatuhan wajib pajak pada Tabel 8 diperoleh nilai signifikasi sebesar 0,041 dengan nilai $t_{\text {hitung }}$ sebesar 2,069. Nilai Signifikansi 0,041 lebih kecil dari tingkat kesalahan yang dapat diterima yaitu 5 persen atau $0,041<0,05$ mengindikasikan bahwa $\mathrm{H}_{0}$ ditolak dan $\mathrm{H}_{4}$ diterima. Hasil ini mempunyai arti bahwa penghasilan wajib pajak berpengaruh positif dan signifikan terhadap kepatuhan wajib pajak.

Berdasarkan hasil analisis pengaruh pemeriksaan pajak terhadap kepatuhan wajib pajak pada Tabel 8 , diperoleh nilai signifikasi sebesar 0,040 dengan nilai $t_{\text {hitung }}$ sebesar 2,089. Nilai Signifikansi 0,040 lebih kecil dari tingkat kesalahan yang dapat diterima yaitu 5 persen atau $0,040<0,05$ mengindikasikan bahwa $\mathrm{H}_{0}$ ditolak dan $\mathrm{H}_{5}$ diterima. Hasil ini mempunyai arti bahwa pemeriksaan pajak berpengaruh positif dan signifikan terhadap kepatuhan wajib pajak.

Hipotesis pertama menyatakan bahwa diemensi keadilan berpengaruh positif dan signifikan terhadap kepatuhan wajib pajak orang pribadi UMKM di 
KPP Pratama Gianyar. Nilai koefesien regresi sebesar 0,148 dan signifikansi sebesar 0,048 lebih kecil dari 0,05 mengindikasikan bahwa $\mathrm{H}_{0}$ ditolak dan $\mathrm{H}_{1}$ diterima.

Hasil ini mendukung theory of planned behavior terkait dengan persepsi positif oleh wajib pajak terhadap adilnya tarif pajak yang berlaku sesuai dengan kemampuan (penghasilan) wajib pajak serta manfaat yang didapatkan ketika melaksanakan kewajiban membayar pajak. Ketika wajib pajak merasa pajak yang dikenakan sesuai dengan kemampuan dan wajib pajak mendapatkan manfaat yang sesuai maka akan memotivasi wajib pajak untuk meningkatkan kepatuhan dalam membayar pajak. Tetapi apabila sebaliknya, maka ini akan mendorong wajib pajak untuk tidak melaksanakan kewajiban perpajakannya.

Hasil ini sejalan dengan penelitian Azmi dan Perumal (2008), yang menyatakan bahwa dimensi keadilan berpengaruh positif terhadap kepatuhan wajib pajak orang pribadi UMKM. Diperkuat dengan penelitian oleh Renata (2016) dan Suryadi (2016) yang memperoleh hasil yang sama.

Hipotesis kedua menyatakan bahwa sosialisasi pajak berpengaruh positif dan signifikan terhadap kepatuhan wajib pajak orang pribadi UMKM di KPP Pratama Gianyar. Nilai koefesien regresi sebesar sebesar 0,266 dan signifikansi sebesar 0,026 lebih kecil dari 0,05 mengindikasikan bahwa $\mathrm{H}_{0}$ ditolak dan $\mathrm{H}_{2}$ diterima.

Hasil ini mendukung theory of planned behavior terkait dengan normative belief, dengan melakukan sosialisasi tidak hanya akan meningkatkan pengetahuan tentang pajak yang nantinya akan berdampak pada peningkatan kepatuhan wajib 
pajak dalam melaksanakan kewajiban perpajakannya. Sosialisasi pajak akan meningkatkan pemahaman wajib pajak baik mengenai prosedur, peraturan pajak terbaru maupun sanksi pajak yang akan diberikan. Hai ini akan memberikan rangsangan atau motivasi terhadap wajib pajak untuk berperilaku patuh.

Hasil penelitian ini sejalan dengan Dharma dan Suardana (2014), Megantara (2017) yang menyatakan bahwa sosialisasi pajak berpengaruh positif terhadap kepatuhan wajib pajak. Selain itu penelitian yang dilakukan oleh Sari (2018) dan Fernando (2018) juga mendapatkan hasil yang sama.

Hipotesis ketiga menyatakan bahwa sanksi pajak berpengaruh positif dan signifikan terhadap kepatuhan wajib pajak orang pribadi UMKM di KPP Pratama Gianyar. Dengan nilai koefesien positif sebesar 0,264 dan signifikansi sebesar 0,017 lebih kecil dari 0,05 mengindikasikan bahwa $\mathrm{H}_{0}$ ditolak dan $\mathrm{H} 3$ diterima.

Hasil ini mendukung theory of planned behavior terkait dengan control belief, dengan adanya kontrol dari sanksi pajak yang tegas dan bersifat memberikan efek jera, wajib pajak akan meningkatkan kepatuhan pajak mereka untuk menghindari sanksi yang akan dikenakan ketika tidak melaksanakan kewajiban membayar pajak. Wajib Pajak juga akan membayarkan pajak sesuai dengan aturan yang berlaku.

Hasil penelitian ini sejalan dengan penelitian sebelumnya yang dilakukan oleh Fuadi dan Yeni (2013) dan Aditya (2015) yang menyatakan bahwa sanksi pajak berpengaruh positif terhadap kepatuhan wajib pajak orang pribadi UMKM. Eben Ezer (2017) juga mendapatkan hasil yang sama. 
Putu Ndiani Putri Utama dan Putu Ery Setiawan. Pengaruh ...

Hipotesis keempat menyatakan bahwa penghasilan wajib pajak berpengaruh positif signifikan terhadap kepatuhan wajib pajak orang pribadi UMKM di KPP Pratama Gianyar dengan nilai koefesien sebesar 0,224 dan signifikansi sebesar 0,041 lebih kecil dari 0,05 mengindikasikan bahwa $\mathrm{H}_{0}$ ditolak dan $\mathrm{H} 4$ diterima

Hasil ini mendukung teroi Atribusi, dimana kepatuhan wajib pajak dipengaruhi oleh faktor internal wajib pajak berupa penghasilan atau keuntungan yang didapatkan wajib pajak dalam menjalankan usaha. Apabila wajib pajak merasa tidak mendapatkan penghasilan atau keuntungan yang cukup, maka mereka akan menggunakan penghasilan tersebut hanya untuk keperluan usaha, dan tidak dapat digunakan untuk membayarkan pajak. Sebaliknya, apabila wajib pajak merasa keuntungan yang didapatkan cukup, maka wajib pajak akan dapat melaksanakan kewajiban membayar pajak.

Hal ini sejalan dengan hasil penelitian Setiawan (2015), Megantara (2017) dan Eben Ezer (2017) yang menyatakan bahwa penghasilan wajib pajak berpengaruh positif terhadap kepatuhan wajib pajak orang pribadi UMKM.

Hipotesis kelima menyatakan bahwa pemeriksaan pajak berpengaruh positif terhadap kepatuhan wajib pajak orang pribadi UMKM di KPP Pratama Gianyar dengan nilai koefesien positif sebesar 0,124 dengan nilai signifikansi sebesar 0,040 lebih kecil dari 0,05 $(0,040<0,05)$, mengindikasikan bahwa $\mathrm{H}_{0}$ ditolak dan $\mathrm{H}_{5}$ diterima.

Hasil ini mendukung theory of planned behavior terkait dengan control belief, dengan adanya pemeriksaan pajak yang rutin dilakukan, wajib pajak akan 
meningkatkan kewaspadaan mereka dengan membayar pajak sesuai dengan aturan yang berlaku demi menghindari adanya sanksi yang diterima ketika pelaksanaan pemeriksaan pajak sehingga, kepatuhan wajib pajak orang pribadi UMKM akan meningkat. Kebijakan pemeriksaan yang diterapkan dapat membentuk persepsi dalam wajib pajak bahwa kemungkinan pemeriksaan pajak akan tinggi, serta sanksi yang akan didapatkan akan berat apabila tidak melaporkan pajak yang sesuai.

Hasil penelitian ini sejalan dengan penelitian sebelumnya yang dilakukan oleh Mandagi (2014) yang menyatakan bahwa pemeriksaan pajak berpengaruh postif terhadap kepatuhan wajib pajak orang pribadi UMKM. Diperkuat dengan penelitian oleh Palupi (2017) dan Eben Ezer (2017) yang mendapatkan hasil yang sama.

Penelitian ini menghasilkan simpulan mengenai pengaruh dimensi keadilan, sosialisasi pajak, sanksi pajak, penghasilan wajib pajak dan pemeriksaan pajak terhadap kepatuhan wajib pajak orang pribadi UMKM di KPP Pratama Gianyar. Adapun hasil uji dari penelitian ini menemukan bahwa variabel independen yaitu dimensi keadilan, sosialisasi pajak, sanksi pajak, penghasilan wajib pajak dan pemeriksaan pajak berpengaruh positif terhadap kepatuhan wajib pajak orang pribadi UMKM.

Penelitian ini mendukung teori Atribusi yang menjelaskan mengenai kepatuhan wajib pajak dapat dipengarui oleh persepsi dari UMKM itu sendiri maupun kesan lingkungan terhadap instansi perpajakan dapat memengaruhi penilaian terhadap pajak, sehingga hal ini dapat memengaruhi kepatuhan wajib 
pajak. Penelitian ini juga mendukung theory of planned behavior yaitu kepatuhan wajib pajak dipengaruhi oleh niat dari wajib pajak itu sendiri untuk memenuhi kewajiban perpajakannya.

Penelitian ini diharapkan dapat memberikan kontribusi baik untuk pemerintah, Direktorat Jendral Pajak maupun KPP Pratama Gianyar untuk dapat meningkatkan sosialisasi mengenai peraturan - peraturan perpajakan terbaru maupun tata cara pembayaran pajak yang benar sehingga wajib pajak akan lebih memahami kewajiban perpajakannya dan meningkatkan kepatuhan wajib pajak.

Sanksi pajak yang tegas dan pemeriksaan pajak dapat dijadikan sebagai alat kontrol untuk wajib pajak melaksanakan kewajibannya membayar pajak. Wajib Pajak UMKM juga diharapkan untuk tepat waktu dalam membayarkan pajak mereka sehingga terhindar dari sanksi pajak. Selain itu dalam membuat peraturan pajak yang baru, sebaiknya selalu mengedepankan keadilan bagi wajib pajak serta penghasilan yang didapatkan wajib pajak. Adapun bagi peneliti selanjutnya, penelitian ini diharapkan dapat menjadi referensi serta sumber pemikiran untuk mengembangkan masalah - masalah baru dalam bidang yang terkait.

\section{SIMPULAN}

Dimensi keadilan berpengaruh positif pada kepatuhan wajib pajak orang pribadi UMKM di KPP Pratama Gianyar. Semakin peraturan perpajakan dirasa adil oleh wajib pajak maka akan semakin tinggi tingkat kepatuhan wajib pajak orang pribadi UMKM. Sosialisasi pajak berpengaruh positif pada kepatuhan wajib pajak 
orang pribadi UMKM di KPP Pratama Gianyar. Pelaksanaan sosialisasi yang berkesinambungan akan menambah pemahaman wajib pajak orang pribadi UMKM akan kewajiban perpajakannya sehingga akan meningkatkan kepatuhan wajib pajak orang pribadi UMKM. Sanksi pajak berpengaruh positif pada kepatuhan wajib pajak orang pribadi UMKM di KPP Pratama Gianyar. Sanksi yang tegas akan meningkatkan kepatuhan wajib pajak. Penghasilan wajib pajak berpengaruh positif pada kepatuhan wajib pajak orang pribadi UMKM di KPP Gianyar. Penghasilan UMKM yang semakin tinggi akan meningkatkan kemampuan UMKM untuk membayar pajak. Pemeriksaan pajak berpengaruh positif pada kepatuhan wajib pajak orang pribadi UMKM di KPP Gianyar. Pelaksanaan pemeriksaan pajak yang rutin dan sesuai aturan akan meningkatkan kepatuhan mereka dalam membayarkan pajak sesuai dengan aturan yang berlaku.

\section{REFERENSI}

Apsari, Dian Tri. (2017). Analisis Faktor-Faktor Yang Mempengaruhi Kepatuhan Wajib Pajak Orang Pribadi di KPP Pratam Sleman. Electronic Theses and Disertation UGM. Retrieved from http://etd.repository.ugm.ac.id/index.php?mod=penelitian_detail\&sub=Pe nelitianDetail\&act=view\&typ=html\&buku_id=128998\&obyek_id=4

Azmi, Anna A. \& Perumal. (2008). Tax Fairness Dimensions In An Asian Context: The Malaysian Perspective. International Review of Business Research Papers, 4(5), 20-27.

Alm, J., Cherry, T., Jones, M., \& McKee, M. (2010). Taxpayer information assistance services and tax compliance behavior. Journal of Economic Psychology. https://doi.org/10.1016/j.joep.2010.03.018

Chau, Gerald \& Leung, P. (2009). A critical review of Fischer's tax compliance model: A Research Synthesis. Journal of Accounting and Taxation, 1(2), 34-40. 
Coolidge, Jacqueline and Domagoj Ilic. (2009). Tax Compliance Perceptions and Formalization of Small Businesses in South Africa. Policy Research Working Paper, pp: 1-40.

Doran, Michael. (2009). Tax Penalties and Tax Compliance, Harvard Journal on Legislation (www.ssrn.com), Vol.46:p:111-161.

Djawani, Behnud M. \& Rene Fahr. (2013). The Impact of Tax Knowledge and Budget Spending Influence on Tax Complience. IZA Disscussion Paper No. 7255.

Ezer, Eben. (2017). Pengaruh Tingkat Pendapatan, Tarif Pajak, Denda Pajak, dan Probabilitas Pemeriksaan Pajak Terhadap Kepatuhan Pajak. Journal of Accounting Diponegoro, 6 (3), 1-13.

Fernando, Fernando \& Anton Arisman. (2018). Pengaruh Sosialisasi Perpajakan, Pengetahuan Perpajakan, dan Sanksi Perpajakan Terhadap Kepatuhan Wajib Pajak Orang Pribadi (Studi Empiris Pada Wajib Pajak Orang Pribadi Yang Terdaftar Di KPP Pratama Palembang Seberang Ulu).Skripsi. STIE MDP.

Forest, Adam \& Sheffrin, Steven M. 2002. Complexity and Compliance: An Empirical Investigation. National Tax Journal, 55(1), 75-88.

Giligan, G. \& Richardson. (2005). Perception of Tax Fairness and Tax Compliance in Australia and Hong Kong - A Preliminary Study. Journal of Financial Crime, 12, 331-343.

Gupta, Ranjana. (2009). An Empirical Study of Demographics of Perceptions of Tax Evasion in New Zealand. Journal of Australian Taxation, 12(1).

Kennedy Prince Modugu, John Obi Adnyaduba PhD. (2014). Impact of Tax Audit on Tax Compliance in Nigeria.

Luthans, Fred. (2002). Organizational Behavior (7th Edition). New York: McGraw-Hill Inc.

Marjan, R. M. (2014). Pengaruh Kesadaran Wajib Pajak, Pelayanan Fiskus, dan Sanksi Pajak terhadap Tingkat Kepatuhan Formal Wajib Pajak (Studi di Kantor Pelayanan Pajak Pratama Makassar Selatan).

Megantara, Kadek. (2017). Pengaruh Penghasilan Wajib Pajak, Sosialisasi Perpajakan, dan Kemauan Membayar Pajak terhadap Kepatuhan Wajib Pajak Usahawan atas Penerapan Peraturan Pemerintah Nomor 46 Tahun 
2013 (Studi Pada Kantor Pelayanan Pajak Pratama Singaraja). Jurnal Ilmiah Akuntansi Undiksha, 7(1).

Menteri Keuangan Indonesia. (2000). Keputusan Menteri Keuangan Republik Indonesia No. 545/KMK.04/2000 tentang Tata Cara Pemeriksaan Pajak (p. $3)$.

Mustikasari, E. (2007). Kajian Empiris tentang Kepatuhan Wajib Pajak Badan di Perusahaan Industri Pengolahan di Surbaya. Simposium Nasional Akuntansi $X$.

Palil, Mohd. Rizal. (2010). Tax Knowledge and Tax Compliance Determinants in Self-Assesment System in Malaysia. PhD Thesis. University of Birmingham.

Peraturan Pemerintah No 46 Tahun 2013 tentang Pajak Penghasilan atas Penghasilan dari Usaha yang Diterima atau Diperoleh Wajib Pajak yang Memiliki Peredaran Bruto Tertentu.

Pris. Andarini K. (2010). Dampak Dimensi Keadilan Pajak Terhadap Tingkat Kepatuhan Wajib Pajak

Richardson, G. (2006). Impact of Tax Fairness Dimensions on Tax Compliance Behavior in an Asian Jurisdiction: The Case of Hong Kong, The.

International Tax Journal.

Sanders, Debra L, Reckers, Philip M.J., \& Iyer, Govind S. (2008). Influence of Accountability and Penalty Awareness on Tax Compliance. The Journal of the American Taxation Association, 30(2), 1 - 20.

Sari, Andini Permata. (2018). Persepsi Tax Amnesty Sebagai Pemoderasi Pengaruh Kesadaran Wajib Pajak dan Sanksi Perpajakan pada Kepatuhan Wajib Pajak Orang Pribadi di Kantor Pelayanan Pajak Pratama Badung Utara. Skripsi. Fakultas Ekonomi dan Bisnis Universitas Udayana.

Suryadi, Dedy. (2016). Pengaruh Dimensi Keadilan Pajak dan Tax Morale terhadap Tingkat kepatuhan Wajib Pajak Badan yang terdaftar di KPP Pratama Kota Bandung. TEDC Jurnal, 10(1), 61-69.

Tarjo, \& Kusumawati, I. (2006). Analisis Perilaku Wajib Pajak Orang Pribadi terhadap Pelaksanaan Self Assesment System: Jurnal Akuntansi \& Auditing Indonesia. 
Putu Ndiani Putri Utama dan Putu Ery Setiawan. Pengaruh ...

Torgler, Benno \& Schneider, Friedrich. (2006). What Shapes Attitudes toward Paying Taxes?. Evidence from Multicultural European Countries. Social Science Quarterly, 88(2), 443-465. 